\title{
Endolymphatic Sac Tumour: A Case Report and Review of the Literature
}

\section{Tumor do saco endolinfático: relato de caso e revisão da literatura}

\author{
Amey P. Patankar ${ }^{10}$ Ranjan Aiyer ${ }^{2}$ Srinivasan Chamarajan ${ }^{3}$ Nidhi Vala $^{3}$ \\ ${ }^{1}$ Department of Neurosurgery, Neuron Hospital, Vadodara, Gujarat, \\ India \\ 2 Department of Ear, Nose and Throat, Baroda Medical College and

\begin{abstract}
Address for correspondence Dr. Amey P. Patankar, MBBS, MS, MCh, Department of Neurosurgery, Neuron Hospital, Sun Pharma Road, Vadodara, Gujarat, India (e-mail: docapp@icloud.com).
\end{abstract} SSC Hospital, Vadodara, Gujarat, India

${ }^{3}$ Department of Pathology, Sterling Hospital, Vadodara, Gujarat, India

Arq Bras Neurocir 2021;40(4):e387-e393.

\author{
Abstract \\ Keywords \\ - endolymphatic sac \\ tumor \\ - temporal bone \\ tumors \\ - Von-Hippel Lindau \\ syndrome
}

\section{Resumo \\ Palavras-chave \\ - tumor do saco endolinfático \\ - tumores do osso temporal \\ - doença de Von-Hippel Lindau}

Introduction Endolymphatic sac tumor (ELST) is a slow-growing, low-grade, locallyinfiltrative tumor arising from the endolymphatic sac/duct, which is located in the posterior part of the petrous temporal bone. It may be sporadic in origin, or may be associated with Von-Hippel Lindau (VHL) syndrome.

Case description A 40-year-old female patient with an ELST without VHL syndrome who was treated successfully by microsurgical extirpation of the tumor.

Discussion We discuss the radiological features and the histopathology of this rare tumor and review the relevant literature.

Conclusion The case herein reported adds to the previously-reported cases of this rare tumor.

Introdução O tumor do saco endolinfático (ELST) é um tumor localmente infiltrativo, de baixo grau e crescimento lento, originado do ducto/saco endolinfático, que está localizado na parte posterior do osso petroso temporal. Pode ser de origem esporádica ou pode estar associado à síndrome de Von-Hippel Lindau (VHL).

Descrição do caso Paciente do sexo feminino, 40 anos, com ELST sem síndrome de VHL, tratada com sucesso por extirpação microcirúrgica do tumor.

Discussão Discutimos as características radiológicas e a histopatologia desse tumor raro e revisamos a literatura relevante.

Conclusão $\mathrm{O}$ caso aqui relatado se soma aos casos previamente relatados desse tumor raro. received

October 31, 2020

accepted

March 9, 2021

published online

August 13, 2021
DOI https://doi.org/ 10.1055/s-0041-1730419. ISSN 0103-5355. (c) 2021. Sociedade Brasileira de Neurocirurgia. All rights reserved. This is an open access article published by Thieme under the terms of the Creative Commons Attribution-NonDerivative-NonCommercial-License, permitting copying and reproduction so long as the original work is given appropriate credit. Contents may not be used for commercial purposes, or adapted, remixed, transformed or built upon. (https://creativecommons.org/ licenses/by-nc-nd/4.0/)

Thieme Revinter Publicações Ltda., Rua do Matoso 170, Rio de Janeiro, RJ, CEP 20270-135, Brazil 


\section{Introduction}

Endolymphatic sac tumor (ELST) is a rare neoplasm originating from the structures of the inner ear, first described by Hassard et al. ${ }^{1}$ in 1984 . Heffner ${ }^{2}$ reported twenty cases of ELST, and suggested the endolymphatic sac as the site of origin of these tumors. Megerian et al. $^{3}$ established its association with Von-Hippel Lindau syndrome.

We report a case of a patient with this rare tumor and review the relevant literature.

\section{Case Description}

A 40-year-old woman presented with headache, vertigo, tinnitus, and decreased hearing in the left ear. An audiometry showed severe sensorineural hearing loss. The function of the cranial nerve was normal, and a fundus examination did not show retinal angiomas. A magnetic resonance imaging (MRI) scan showed a heterogeneous multilobulated lesion in the left mastoid bone with cystic areas and septa. The lesion was hypointense in $\mathrm{T} 1$, with few hyperintense areas (-Fig. 1), heterogenously hyperintense in T2 (-Fig. 2), with heterogenous contrast enhancement (-Fig. 3). The lesion extended into posterior fossa, compressing the cerebellum. The possibility of a bone lesion (bone cyst, eosinophilic granuloma, cholesteatoma) was considered preoperatiely.

\section{Operative Technique}

The patient was operated by a combined retromastoid and transmastoid approach. A curvilinear incision was made $2 \mathrm{~cm}$ behind the tip of the mastoid, curving anteriorly. The mastoid bone was eroded by the lesion, with multiple holes through which the tumor was visible. The tumor was found eroding all the mastoid cells and the dural and sinus plate.

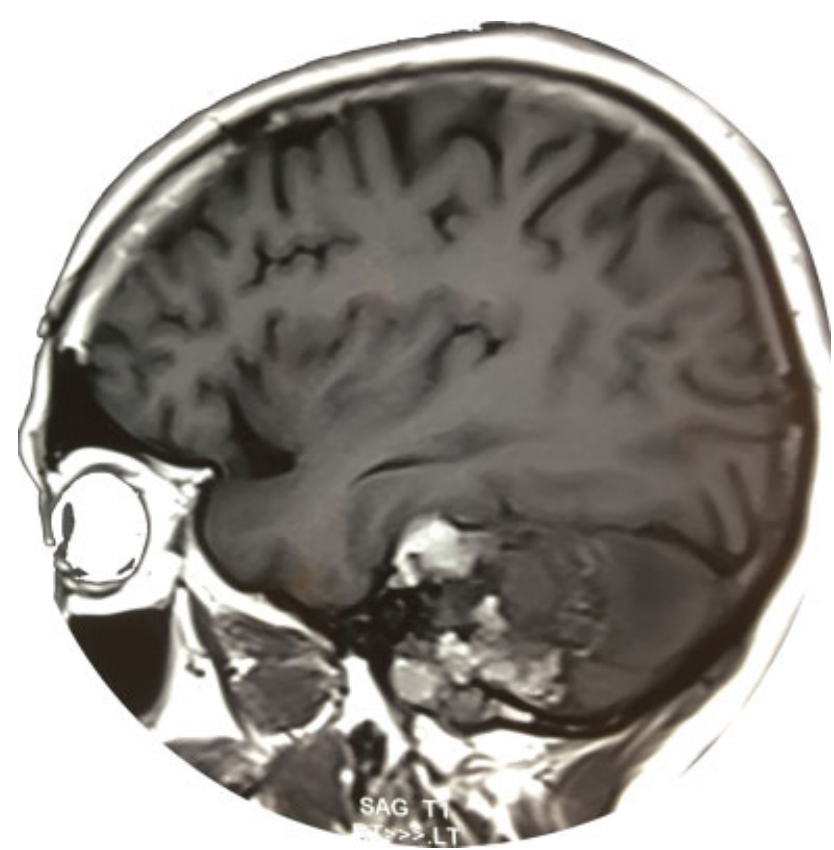

Fig. 1 T1-weighted sagittal showing ian sointense tumor with scattered areas of hyperintensity.

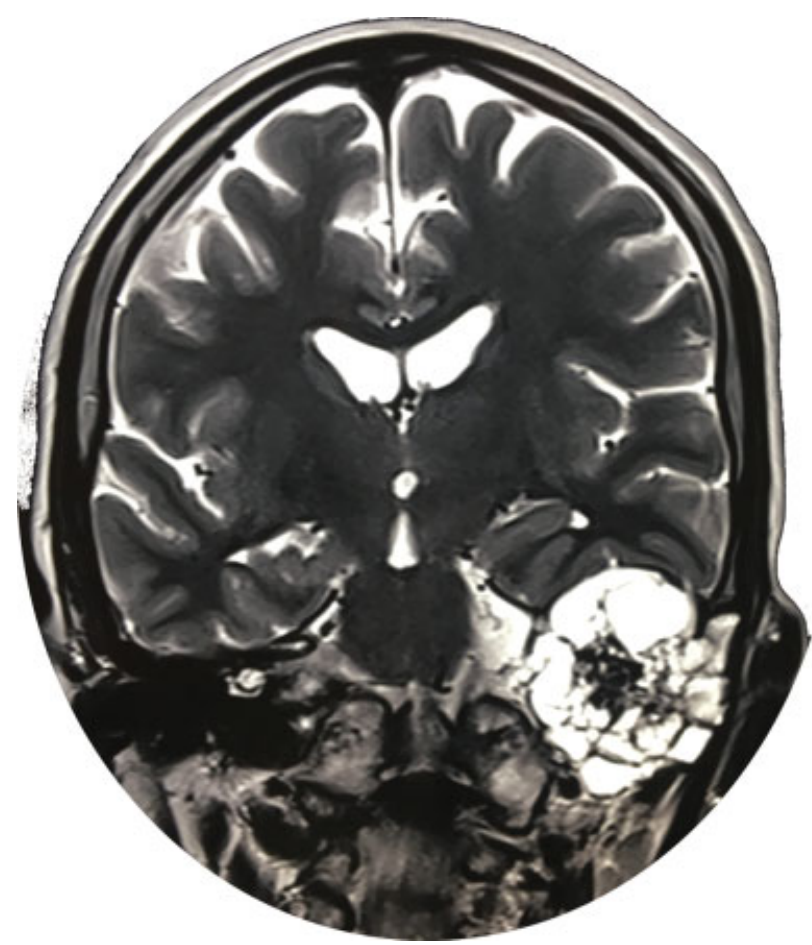

Fig. 2 T2-weighted coronal image showing the hyperintense tumor with few hypointense signals.

The Macewan triangle was exposed, and the tumor in the mastoid was removed piecemeal, and the sinodural angle was gradually cleared. The dural and sinus plates were drilled and skeletonised. The rest of the mastoid cells were

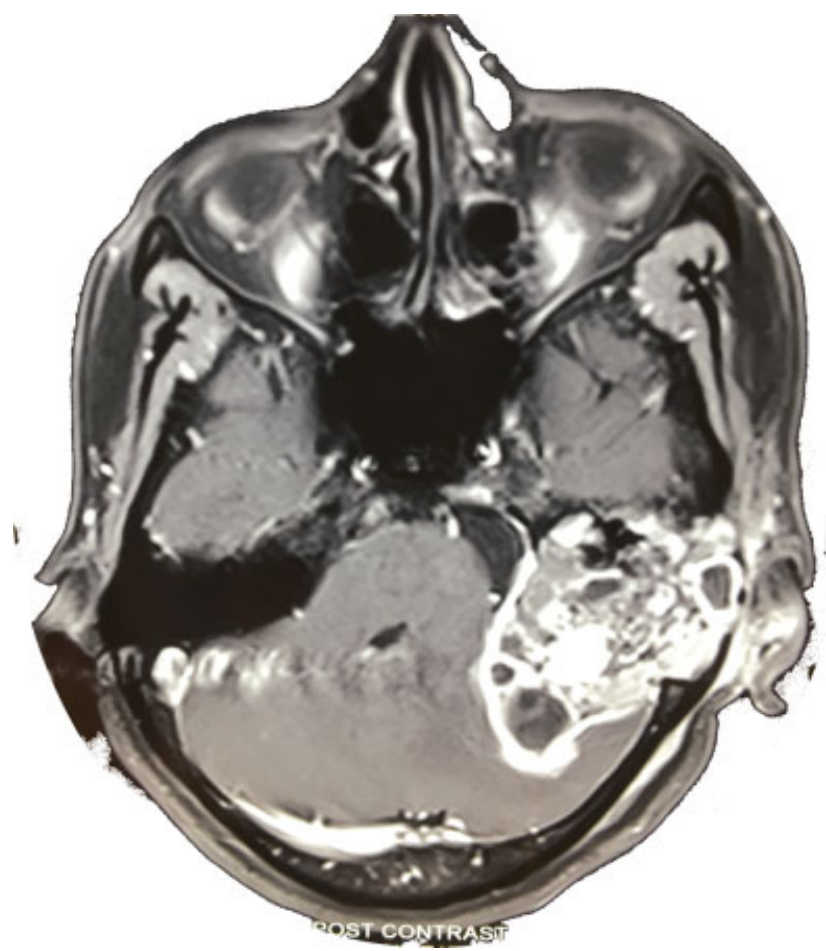

Fig. 3 Postcontrast image showing heterogenous enhancement and internal cystic non-enhancing areas. 
exenterated and the posterior canal wall was lowered until the facial nerve. The middle-ear mucosa was cleared along with the ossicles, and the canal skin was removed in a cuff fashion and was closed like a cul-de-sac. The opening of the Eustachian tube was plugged with muscle pieces. The mastoid cavity was obliterated with fat.

A retromastoid craniotomy was performed to expose the dura of the posterior fossa. The dura was opened, and the cerebrospinal fluid (CSF) was released from the cerebellomedullary cistern to relax the cerebellum. The tumor was debulked, and the capsule was dissected off the cerebellar surface, preserving the arachnoid membrane. As the capsule was dissected, the lower cranial nerves, as well as the seventh and eighth nerve complex, were visualized. The tumor could be easily dissected off the nerve bundles because of the welldefined arachnoid plane. The whole tumor was removed. Fat and the fascia lata were used to close the defect and achieve a watertight closure. The muscles were approximated, and the incision was closed in a standard fashion.

\section{Postoperative Course}

Postoperatively, the patient developed left-sided total facial nerve palsy. On the fifth postoperative day, she developed CSF otorrhea, for which she was reoperated. A vascularised temporalis muscle flap was rotated and placed over the external auditory canal and the middle-ear cavity to completely seal off the middle- and external-ear defects. The patient was discharged on the seventh day after the second surgery. The stitches were removed on the 14 th postoperative day. Left-side tarsorrhaphy was performed in the third month to protect the cornea.

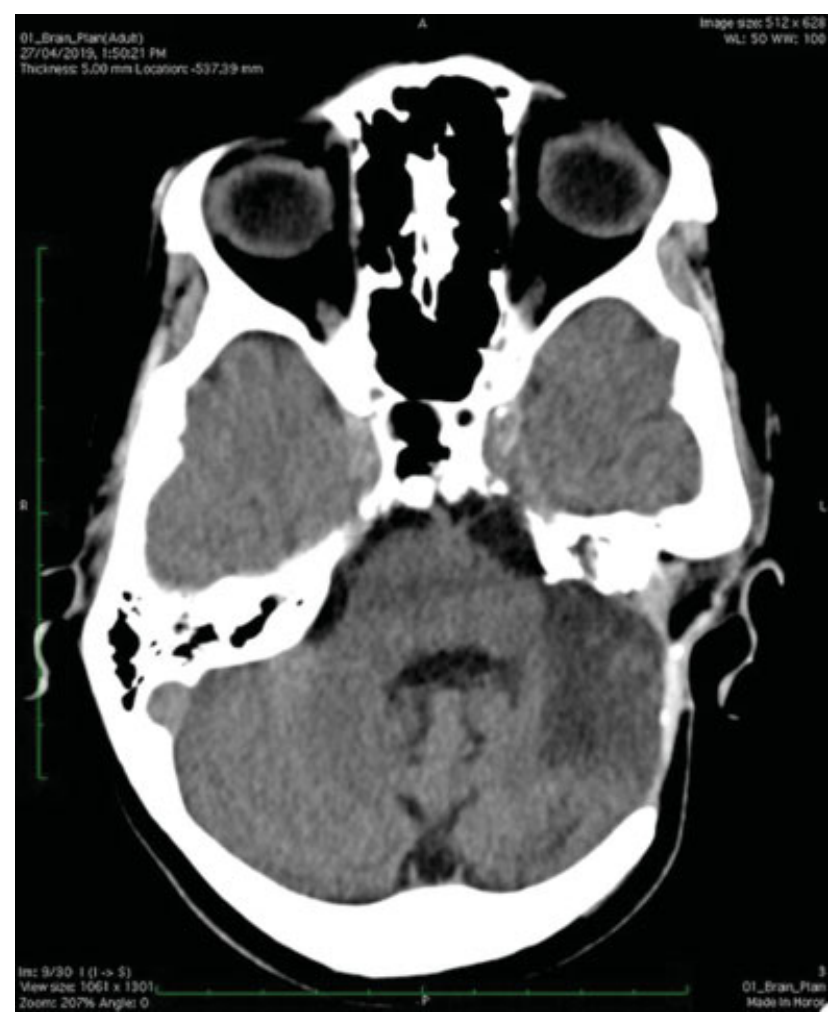

Fig. 4 Postoperative CT scan showing complete tumor removal.

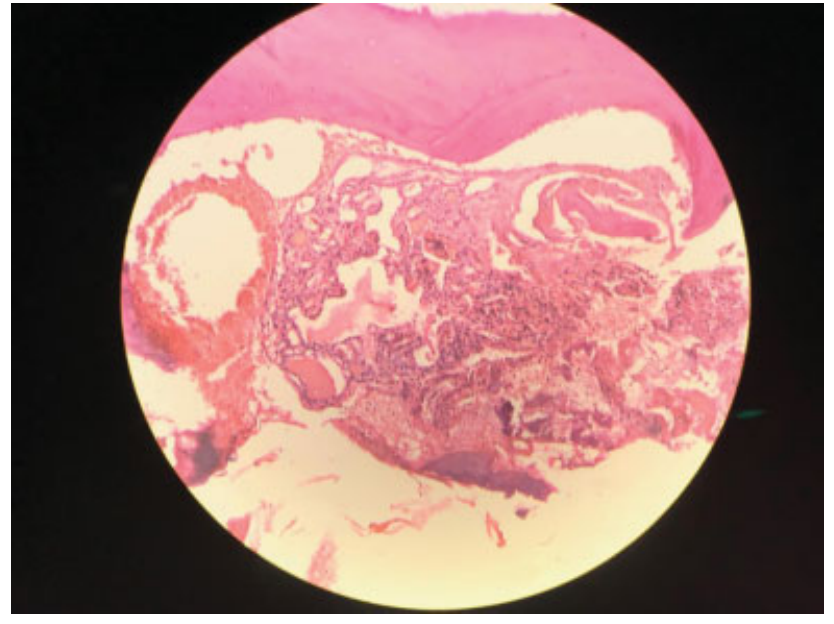

Fig. $510 x$ view of hematoxylin and eosin (H\&E) stain showing papillary structures with a fibrovascular core lined by a single layer of cuboidal cells.

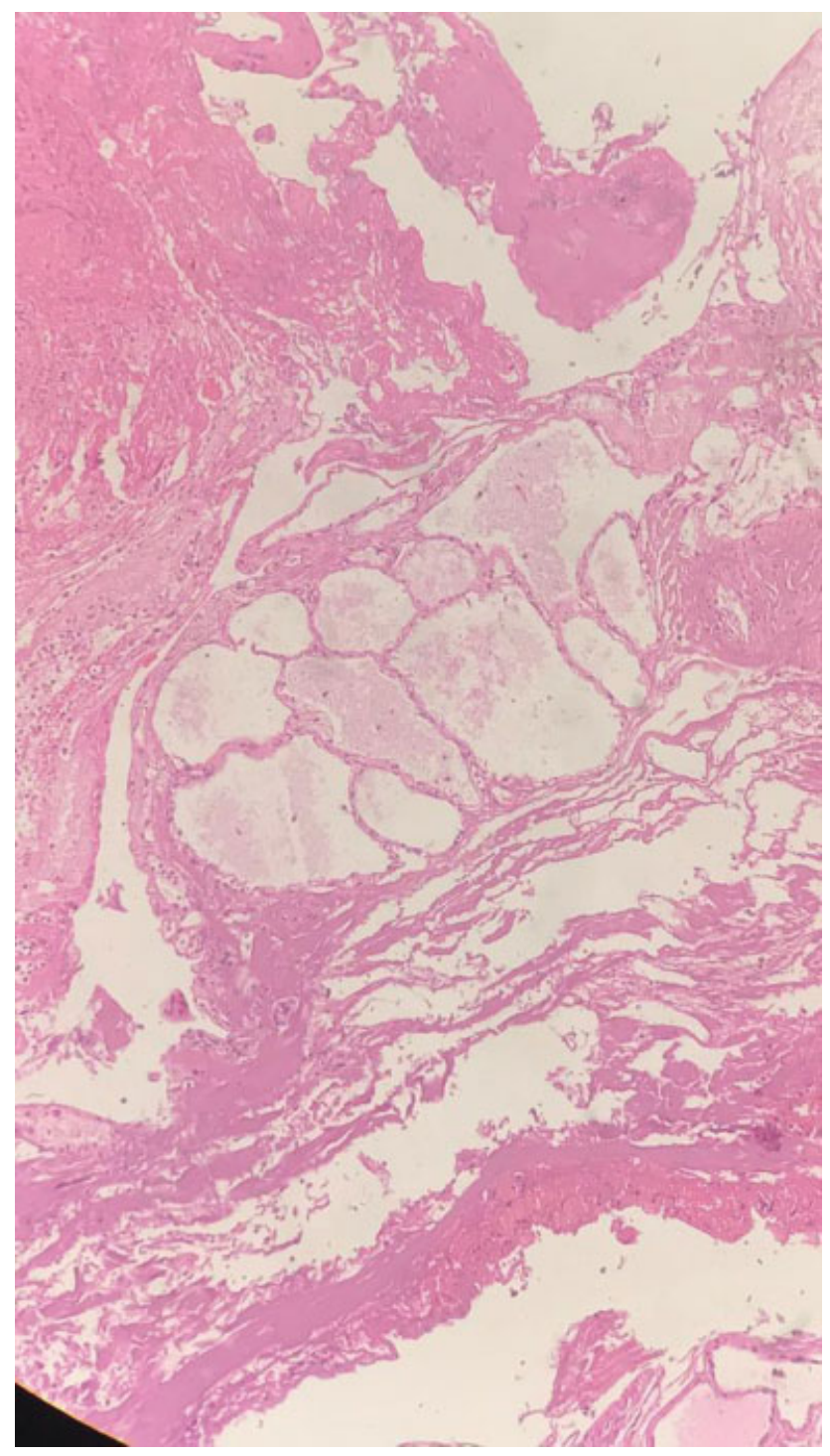

Fig. $610 x$ view showing cystic spaces lined by a single layer of cuboidal cells. 


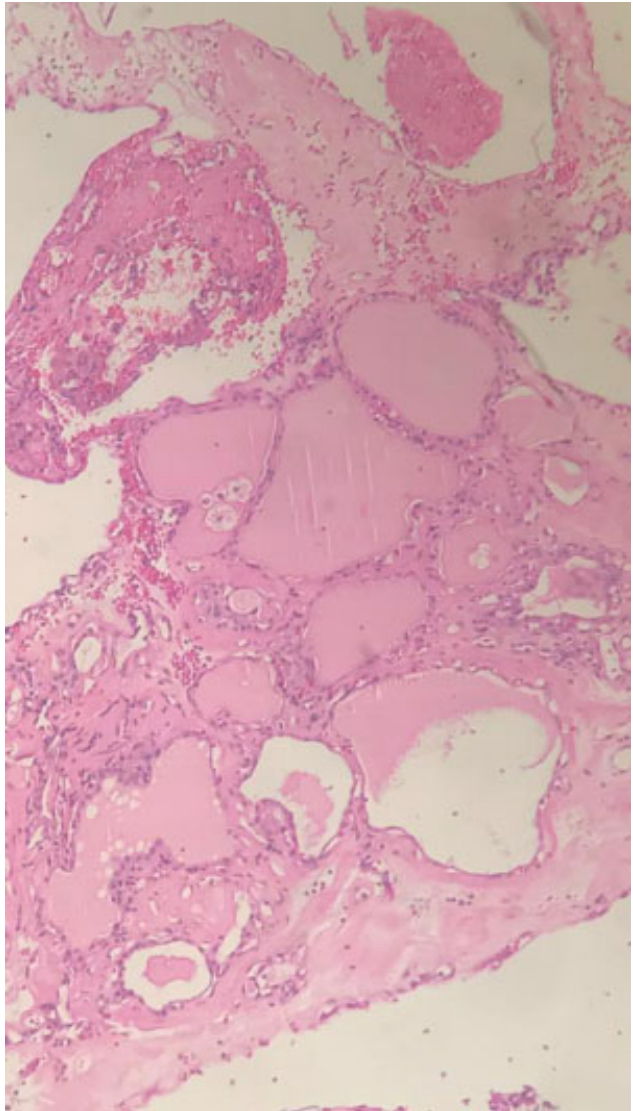

Fig. 7 10x view showing thyroidisation.

A postoperative CT scan showed total removal of the lesion (-Fig. 4).

A histopathology exam revealed papillary and cystic structures, lined by a single layer of cuboidal cells (-Fig. 5-6) with areas of hemorrhage, fibrosis, and cholesterol clefts. Hemosiderin-laden macrophages and cystic glandular spaces were observed filled with a colloid-like material, reminiscent of thyroid tissue ( - Fig. 7 ). The immunohistochemistry revealed positive staining for cytokeratin

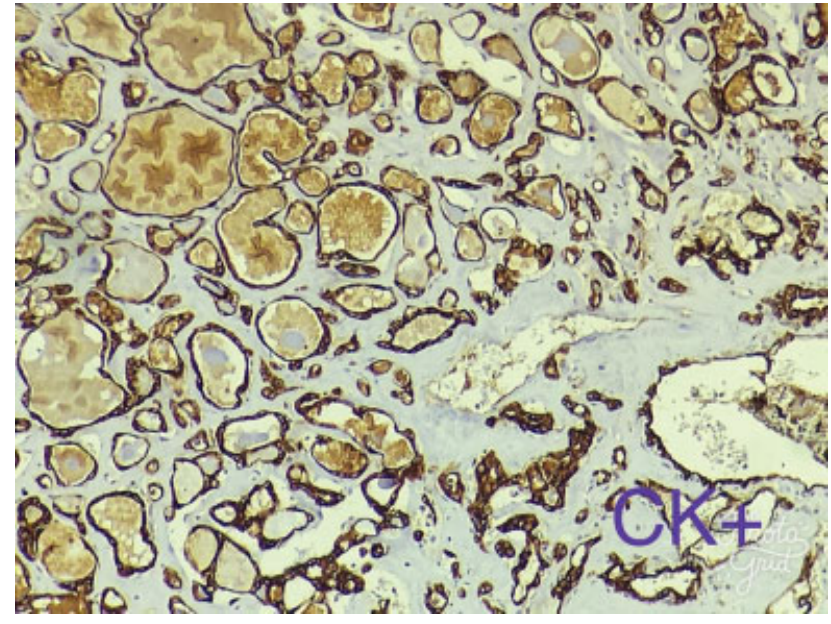

Fig. 8 Immunohistochemistry slide showing positive staining for cytokeratin.

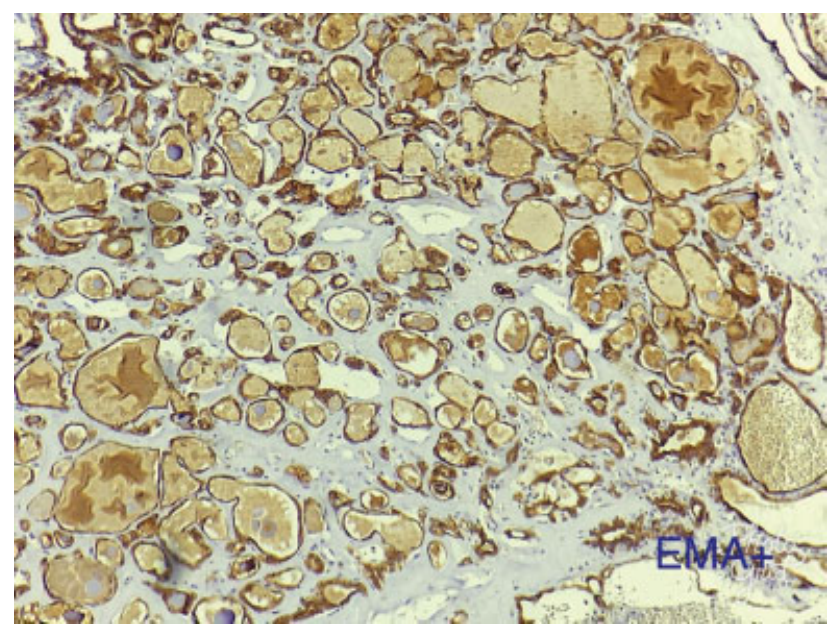

Fig. 10 Immunohistochemistry slide showing positive staining for epithelial membrane antigen.

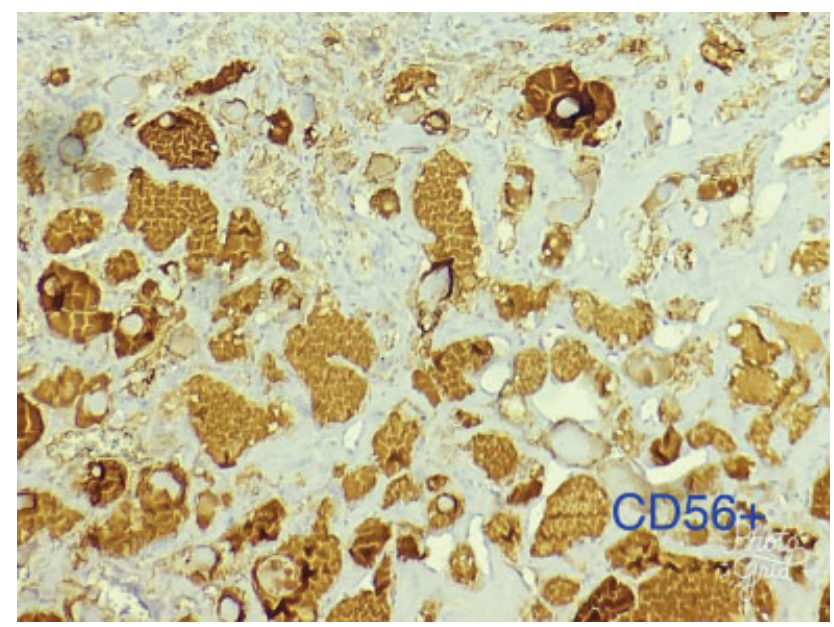

Fig. 11 Immunohistochemistry slide showing positive staining for

neural cell adhesion molecule.
Fig. 9 Immunohistochemistry slide showing positive staining for glia

fibrillary acidic protein.

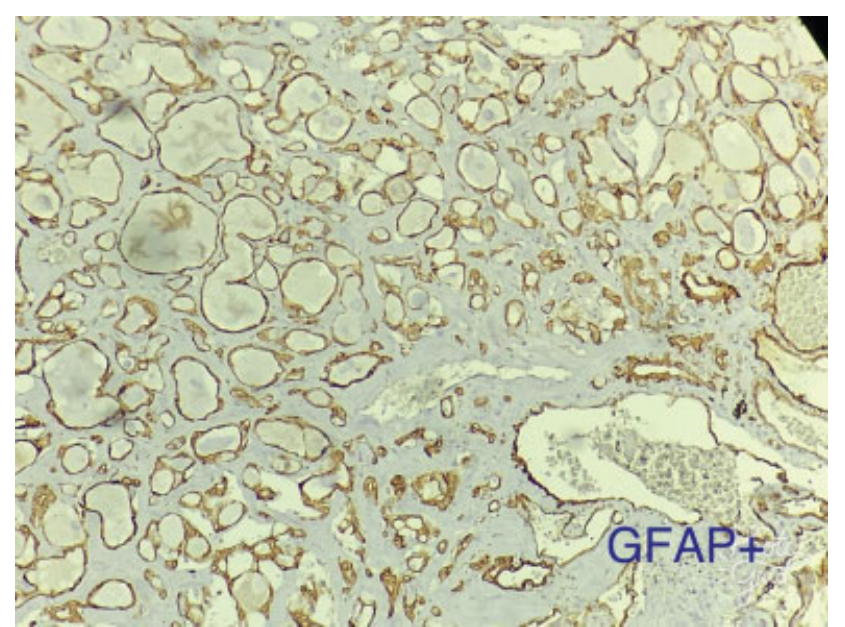




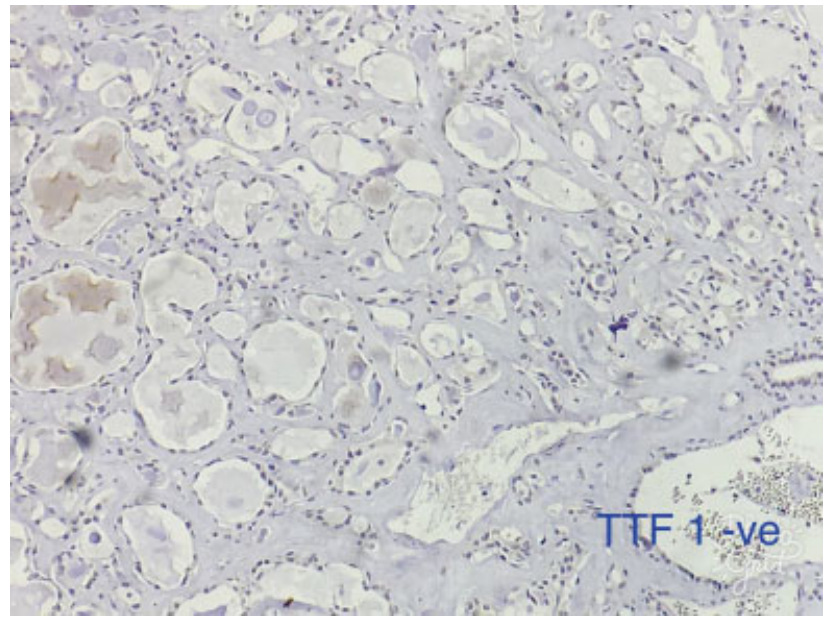

Fig. 12 Immunohistochemistry slide showing negative staining for thyroid transcription factor 1 .

(-Fig. 8), glial fibrillary acidic protein (-Fig. 9), epithelial membrane antigen ( $\mathbf{- F i g}$. 10), neural cell adhesion molecule (NCAM, also known as CD56) (- Fig. 11), and negative staining for thyroid transcription factor-1(-Fig. 12) (which is positive in case of metastatic thyroid and lung carcinoma), synaptophysin (-Fig. 13) and chromogranin (-Fig. 14) (which is positive in cases of paraganglioma), confirming the diagnosis of ELST.

Ultrasonography of the abdomen showed no renal and pancreatic cyst. The fundus examination and the ultrasonography findings ruled out VHL disease in this patient. A computed tomography (CT) scan after four years showed no recurrence of the tumor (-Fig. 15).

\section{Discussion and Evaluation}

With $\sim 200$ reported cases to date, ${ }^{4}$ ELSTs are rare, and most commonly occur in the fifth and sixth decades of life. They may be sporadic or associated with VHL syndrome.- Table 1 shows the difference between sporadic and VHL-associated ELST. The estimated prevalence of ELST in VHL disease is

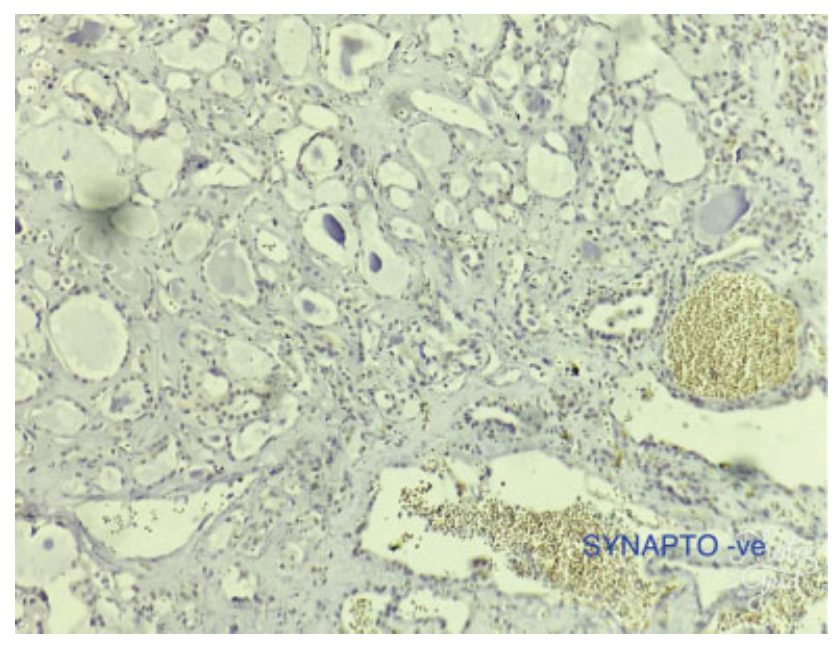

Fig. 14 Immunohistochemistry slide showing negative staining for synaptophysin.

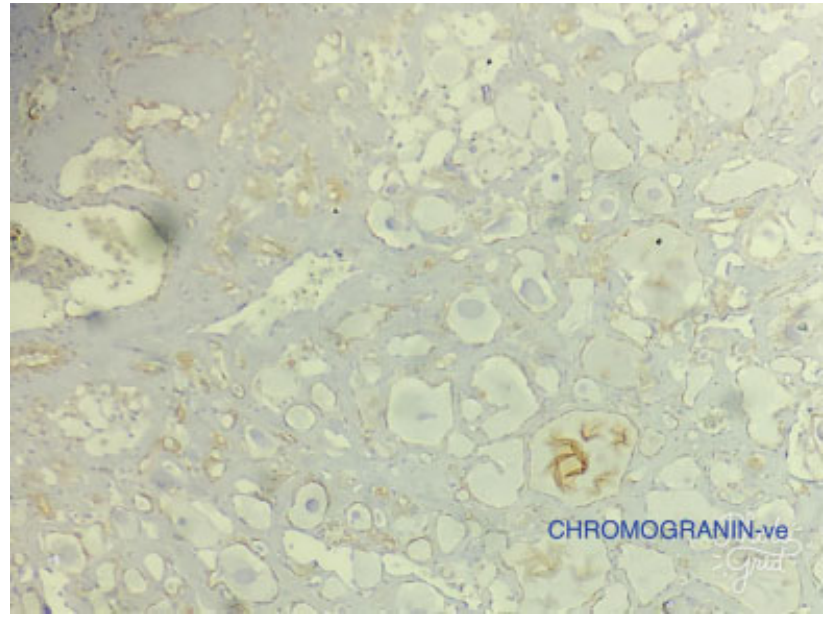

Fig. 13 Immunohistochemistry slide showing negative staining for chromogranin.

between $11 \%$ and $25 \%{ }^{4,5}$ Though distant metastasis has not been reported, "drop metastasis" to the spinal column has been reported. ${ }^{6,7}$ Radiologically, a preoperative diagnosis of an ELST is challenging. The differentials include paraganglioma choroid plexus tumor, metastasis, eosinophilic granuloma, meningioma, arachnoid granulation, aneurysmal bone cyst, or a primary bone tumor.

Lo et al. $^{8}$ and Mukherji et al. ${ }^{9}$ described the characteristic radiological features of ELSTs. Upon CT, ELSTs are observed as erosive lesions with central spiculated calcification and a thin peripheral rim of calcification. Upon MRI, they have areas of hyperintensity on T1-weighted images, with rim or

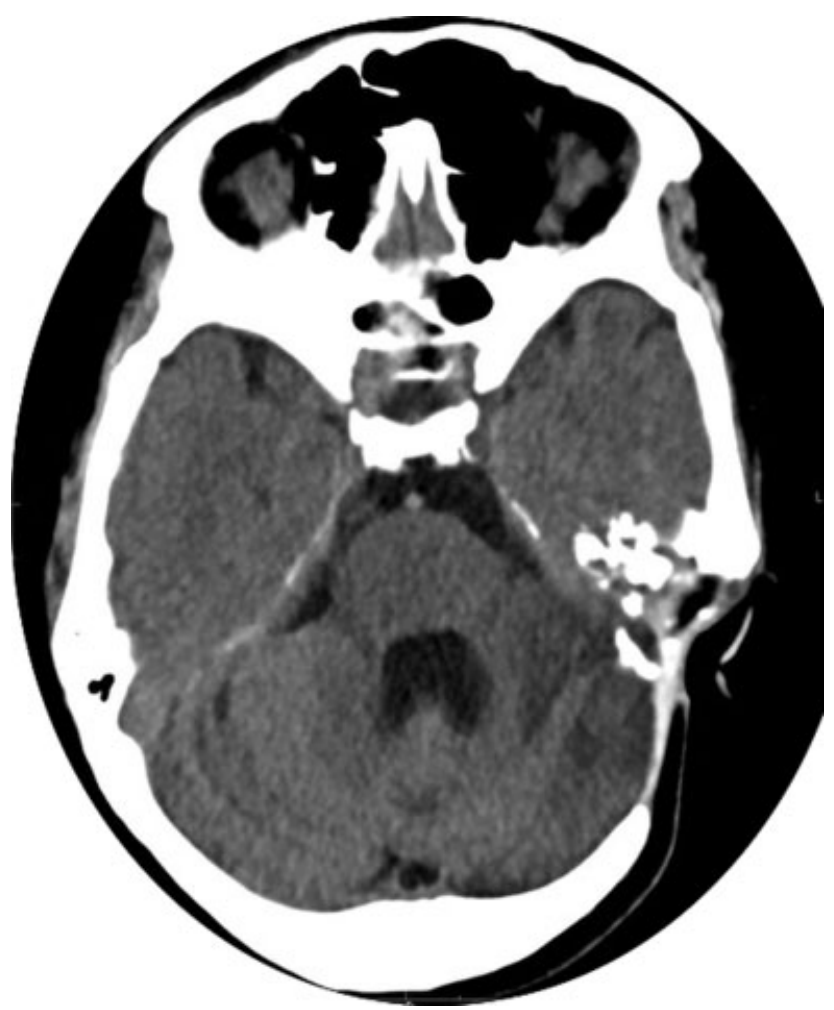

Fig. 15 Postoperative CT scan at 4 years of follow-up showing no recurrence of the tumor. 
Table 1 Difference between sporadic and VHL-associated ELST

\begin{tabular}{|l|l|l|}
\hline & Sporadic ELST & VHL-associated ELST \\
\hline Age at occurrence & Fifth to sixth decades of life & Usually occur earlier, in the third or fourth decades of life \\
\hline Sex predilection (M:F) & $1: 1$ & $1: 2$ \\
\hline Side of occurrence & Mostly unilateral & Bilateral in 30\% (4) of the patients with VHL \\
\hline
\end{tabular}

Abbreviations: ELST, Endolymphatic sac tumor; F, female; M, male; VHL, Von-Hippel Lindau syndrome.

Table 2 Grading and treatment system for endolymphatic sac tumor

\begin{tabular}{|l|l|l|}
\hline Grade & Tumor extent & Surgical approach \\
\hline & $\begin{array}{l}\text { Confined to the temporal bone, middle-ear } \\
\text { cavity, and/or external auditory canal }\end{array}$ & $\begin{array}{l}\text { Hearing preservation with retrolabyrinthine } \\
\text { transdural approach }\end{array}$ \\
\hline 2 & Extension into the posterior fossa & $\begin{array}{l}\text { Extended retrolabyrinthine transdural approach, } \\
\text { approach with labyrinthectomy if hearing is poor }\end{array}$ \\
\hline 3 & Extension into posterior fossa and middle cranial fossa & Subtemporal craniotomy with petrosectomy approach \\
\hline 4 & Extension to clivus and/or sphenoid wing & Staged anterior and posterior fossa techniques \\
\hline
\end{tabular}

multiple foci of hyperintense signals. On T2-weighted images, ELSTs are heterogeneously hyperintense, with heterogeneous contrast enhancement. Bambakidis et al. ${ }^{10}$ devised a grading system to plan the surgical approach (-Table 2).

Surgery remains the mainstay of treatment. Radical resection of the tumor, whenever possible, is the goal of surgery.

Friedman et al. ${ }^{11}$ reported a disease-free survival of $89 \%$, and a rate of preservation of the facial nerve of $83 \%$ following surgery. Stereotactic radiosurgery is used in recurrent cases, for subtotal resections, or when the patient is unfit for surgery. ${ }^{12}$

Histologically, ELSTs show two distinct patterns on light microscopy: papillary and follicular. Some tumors may display both the features, as in the case herein reported. Endolymphatic sac tumors are positive for cytokeratin and epithelial membrane antigen (EMA), and mostly CD56-positive, but they are negative for chromogranin and synaptophysin, as opposed to paragangliomas, and also negative for thyroglobulin, which differentiates them from metastatic thyroid cancer.

\section{Conclusion}

Endolymphatic sac tumors are rare tumors of the temporal bone. Screening for them is recommended in patients with VHL to detect the lesions at an early stage when hearingpreservation surgery is possible.

\section{Declarations}

We the authors confirm that neither this manuscript nor parts of it have been submitted for publication anywhere.

Ethics approval and consent to participate

The case report was presented before the Neuron Hospital Ethics Committee, which, after due review and deliberation, has given the consent for the publication of this article on June $1^{\text {st }}, 2020$.

\section{Consent for publication}

We the authors give consent to Brazilian Neurosurgery to publish our study. We also confirm that consent for publication of the case and photographs has been obtained from the patient.

Availability of data and materials

The present study does not contain any data or materials from other sources. The data supporting the results can be found in the hospitals where the surgery was performed, namely the SSG Hospital and Sterling hospital, Vadodara Gujarat, India.

\section{Authors' Contributions}

Dr. APP was involved involved in treating the patient, and in preparing the manuscript and its submission. Dr. RA was involved in treating the patient, and contributed to the operative technique section. Dr. SC and Dr. NV were the pathologists who provided the pathological diagnosis, and they contributed to the sections on histopathology and immunohistochemistry, and took the photographs.

\section{Funding}

The authors confirm that they have not received any funding for this study from any source.

Conflict of Interests

The authors have no conflict of interests to declare.

\section{References}

1 Hassard AD, Boudreau SF, Cron CC. Adenoma of the endolymphatic sac. J Otolaryngol 1984;13(04):213-216

2 Heffner DK. Low-grade adenocarcinoma of probable endolymphatic sac origin: a clinicopathologic study of 20 cases. Cancer 1989;64:2292-3022 
3 Megerian CA, McKenna MJ, Nuss RC, et al. Endolymphatic sac tumors: histopathologic confirmation, clinical characterization, and implication in von Hippel-Lindau disease. Laryngoscope 1995;105(8 Pt 1):801-808

4 Wick CC, Manzoor NF, Semaan MT, Megerian CA. Endolymphatic sac tumors. Otolaryngol Clin North Am 2015;48(02):317-330

5 Zanoletti E, Girasoli L, Borsetto D, Opocher G, Mazzoni A, Martini A. Endolymphatic sac tumour in von Hippel-Lindau disease: management strategies. Acta Otorhinolaryngol Ital 2017;37 (05):423-429. Doi: 10.14639/0392-100X-1402

6 Tay KY, Yu E, Kassel E. Spinal metastasis from endolymphatic sac tumor. AJNR Am J Neuroradiol 2007;28(04):613-614

7 Bambakidis NC, Rodrigue T, Megerian CA, Ratcheson RA. Endolymphatic sac tumor metastatic to the spine. Case report. J Neurosurg Spine 2005;3(01):68-70
8 Lo WW, Applegate LJ, Carberry JN, et al. Endolymphatic sac tumors: radiologic appearance. Radiology 1993;189(01):199-204

9 Mukherji SK, Albernaz VS, Lo WW, et al. Papillary endolymphatic sac tumors: CT, MR imaging, and angiographic findings in 20 patients. Radiology 1997;202(03):801-808

10 Bambakidis NC, Megerian CA, Ratcheson RA. Differential grading of endolymphatic sac tumor extension by virtue of von Hippel-Lindau disease status. Otol Neurotol 2004;25(05): 773-781

11 Friedman RA, Hoa M, Brackmann DE. Surgical management of endolymphatic sac tumors. J Neurol Surg B Skull Base 2013;74 (01):12-19. Doi: 10.1055/s-0032-1329622

12 Kefeli AU, Yilmaz M, Sengoz M, Peker S. Gamma Knife Radiosurgery for Tumors of the Endolymphatic Sac. Turk Neurosurg 2017; 27(04):665-669 